\title{
Vital Signs Data Collection Date Time
}

National Cancer Institute

\section{Source}

National Cancer Institute. Vital Signs Data Collection Date Time. NCI Thesaurus. Code C83454.

The date and time vital signs data was collected. 